\title{
Resources on the Net
}

\author{
New and Expanding Roles for Libraries \\ Compiled by Chris Bober
}

\section{The Library as Publisher}

Brown, A. P. (Ed.). (2013). Library publishing toolkit. Retrieved from http://opensuny.org/omp/index.php/IDSProject/catalog/book/25

The Library Publishing Toolkit, a 400 page ebook launched on August 1, 2013, offers libraries interested in expanding into publishing a resource "to identify trends in library publishing, seek out best practices to implement and support such programs, and share the best tools and resources." A product of the combined efforts of Milne Library at SUNY Geneseo and the Monroe County Library System, the Library Publishing Toolkit "looks at the broad and varied landscape of library publishing through discussions, case studies, and shared resources." The book is divided into sections on public and academic libraries, with the majority of the book concentrating on the academic environment. Of particular note is a chapter devoted to the publishing of books and ebooks, and three chapters profiling various aspects of the library as journal publisher.

Library Publishing Coalition. (n.d.). Library publishing directory. Retrieved from http://www.librarypublishing.org/resources/directory

Now in its second year, the 2015 edition of the Library Publishing Directory provides insights into the evolving publishing activities of 124 academic and research libraries, the majority of which are located in North America. The aim of this resource is " to articulate the unique value of library publishing; establish it as a significant and growing community of practice; and to raise its visibility within a number of stakeholder communities, including administrators, funding agencies, other scholarly publishers, librarians, and content creators." The Directory can be downloaded in PDF or EPUB formats. Brigham Young University library provides a searchable interface to the directory: http://atom.lib.byu.edu/lpc

Skinner, K., Lippincott, S., Speer, J., \& Walters, T. (2014, Spring). Library-as-publisher: Capacity building for the library publishing subfield. Journal of Electronic Publishing 17(2), http://dx.doi.org/10.3998/3336451.0017.207

Although academic and research libraries are increasingly assuming the role of publisher, evidence reveals the lack of a specialized skill set needed to succeed in this new role. Opportunities for training in library publishing are absent from existing graduate level and continuing professional education programs, leaving practitioners unprepared for the many challenges ahead. The authors provide a brief history of publisher training and incorporate findings from interviews conducted with representatives from a diverse range of publishing sectors. As for the additional educational requirements to enable these ventures to flourish, the author's recommend a combination of "short-term, lightweight, and lower investment training mechanisms to teach practices and hard skills, and longer-term, more structured, and higher investment educational programs to teach the soft skills and inculcate values that fluctuate less rapidly."

\section{Libraries and Open Educational Resources (OER)}

Kazakoff-Lane, C. (n.d.). Environmental scan and assessment of OERs, MOOCs and libraries: What effectiveness and sustainability means for libraries' impact on open education. Retrieved from the Association of College \& Research Libraries website: 
http://www.ala.org/acrl/sites/ala.org.acrl/files/content/publications/whitepapers/Envi ronmental $\% 20$ Scan $\% 20$ and $\% 20$ Assessment.pdf

This ACRL sponsored White Paper, published in March 2014, provides a useful introduction and background information on the open educational resources (OER) and massive open online course (MOOC) movements. Kazakoff-Lane, a librarian at Brandon University (Manitoba), believes that libraries should support open education, but should first be made aware of the many challenges that both OERs and MOOCs face related to their effectiveness and sustainability. In addition, research has shown that OERs lack faculty and student awareness. In spite of these challenges, Kazakoff-Lane recommends that "Libraries can and should play a central role ... and in so doing ensure that their institutions and users are best served by a sober look at the pros and cons of different models of openness for learners, educators, institutions, and governments, not just in the immediate future, but in the long term as well."

\section{OER Research Hub. (n.d.). OER evidence report 2013-2014: Building understanding of open education. Retrieved from: http://oerresearchhub.files.wordpress.com/2014/11/oerrh-evidence-report-2014.pdf}

The Open Educational Research (OER) Hub, created in 2012 and based at Open University (UK), is an ongoing project that has formulated eleven hypotheses in response to the question "What is the impact of OER on learning and teaching practices?" Working in collaboration with 15 targeted institutions that have invested in OER initiatives, this interim report sheds light on the two main hypotheses under investigation: (A) that OER improves student performance; (B) that openly licensed educational resources contributes to their being used differently from nonopen online resources. Survey research has demonstrated that the implementation of OER has an indirect role in improving student performance, measured by increased confidence, satisfaction and enthusiasm for the subject. A wide array of factors influence the use of a resource, and the difficulty of isolating the distinctiveness of open educational resources has proven to be a barrier to obtaining meaningful data. It was observed that openness clearly encourages users to adapt the content and "it allows a continuum of adaptation to develop, ranging from adapting ideas for their own material to full 'reversioning' of content."

Open Textbook Library. (n.d.). Retrieved from University of Minnesota website: http://open.umn.edu/opentextbooks/

The University of Minnesota's College of Education and Human Development, in partnership with a number of other North American colleges, have produced a searchable catalog of free, open, peer reviewed textbooks. The subject browsable catalog features over 150 individual titles suitable for survey level college courses and covers all major disciplines. They are offered in e-book format free of charge, and some are available as print on demand at cost. All textbooks are available under various creative commons opencontent licenses and can be edited to fit the needs of a specific course.

Rice University. (n.d.). OpenStax College. Retrieved from http://openstaxcollege.org/

OpenStax College, Rice University's non-profit publishing venture, was launched in 2012 with the goal of providing free online, peer reviewed introductory textbooks for 25 of the most popular U.S. college courses. To date, eleven textbooks have been produced via Connexions, Rice's open education platform, with plans to extend to twenty one titles by 2017. Costs for producing each of these textbooks can run as high as $\$ 1$ million. Savings to students have so far amounted to over $\$ 13$ million. Funding for this project is spearheaded by a number of philanthropic partners including the William and Flora Hewlett Foundation, 
and the Bill and Melinda Gates Foundation. In August 2014, OpenStax College announced its expansion into the K-12 sector, investing \$9 million to develop free online textbooks for high schools.

\section{Library Responses to Increased User Expectations}

Caperon, L. (2014, November). Developing adaptable, efficient mobile library services:

Librarians as enablers. Ariadne 73, Retrieved from

http://www.ariadne.ac.uk/issue73/caperon

Caperon's case study research at Leeds University Library (U.K.) evaluated the potential needs of mobile device (smartphone) users for library mobile services. Analysis of online questionnaires and focus groups led to the creation of a mobile services toolkit, a flexible model for delivering library mobile services that can respond to the evolving technological advances posed by mobile devices. Caperon believes that the toolkit developed at Leeds University Library is transferable to other institutions and stresses "the importance of developing an adaptable service model which will change with new mobile technologies."

Farelly, D., \& Hutchinson, J. (2013). Streaming video in academic libraries: Preliminary results from a national survey. [Powerpoint slides]. Retrieved from Arizona State Libraries website: http://hdl.handle.net/2286/R.A.118115

Based on their Survey of Academic Streaming Video (SASV), developed and distributed in Spring 2013, Farelly and Hutchinson presented an overview of the survey instrument and initial findings at the 2013 Charleston Conference. The survey results helped to document the current state of streaming video in academic libraries, including its prevalence, the personnel responsible for offering it, the varied number of hosting platforms, how users are discovering and accessing the content, and the level of library resources needed to maintain and develop it. The authors provide a detailed account of the survey results in the November 2014 issue of Against the Grain and they also plan to conduct a follow up study.

Goedeken, E.A., \& Lawson, K.G. (2015). The past, present, and future of demand driven acquisitions in academic libraries. Retrieved from the Iowa State University Digital Repository website: http://lib.dr.iastate.edu/libcat pubs/60/ Driven by recent challenges to building effective and appropriate library collections, the authors investigated how ebooks added to Iowa State University Library's collections through Demand Driven Acquisitions (DDA), a "disruptive technology", compared with titles purchased by selection librarians. It was shown that for science disciplines, there was a significant difference between the number of titles selected by librarians compared with those selected by patrons. However, in the social sciences and humanities disciplines, similar numbers were produced by both of these selector groups. The study also demonstrated that DDA favored ebook purchases over leased ebooks, and the permanence of these collections decisions meant that collection development risked being driven by patron short-term interests over librarian long-term interests: "comparative data generated by patrons versus librarians must be analyzed carefully to make sure that the library selector is not overly influenced by temporal decisions driven by short-term information needs." This is a post-print of an article accepted for publication in College \& Research Libraries, with an anticipated publication date of March 1, 2015.

Ramsey, E., \& Vecchione A. (2014). Channeling passions: Developing a successful social media strategy. Journal of Library Innovation, 5(2), 71-82. Retrieved from http://www.libraryinnovation.org/article/view/359

Ramsey and Vechionne (Albertson Library, Boise State University) discuss the formulation and evolution of a social media strategy and they offer best practice tips to ensure its 
continued success. They recommend keeping the social media strategy flexible enough to allow for experimenting with new technologies as they appear. Assessment of existing tools is an imperative "By using the analytical tools provided by most social networks, libraries can garner the evidence they need to bolster or change that strategy to make sure their social media networks are meeting the needs of their users." Guidelines are provided in the appendix.

Compiler's note: Text that is enclosed within quotations marks has been taken directly from the source document.

\section{Chris Bober}

Education Librarian

Concordia University Libraries

Montreal, Quebec

chris.bober@,concordia.ca 